\title{
原位置岩盤ねじりせん断試験による 異方性岩盤の変形特性の特定方法
}

\author{
富樫陽太 $1 \cdot$ 谷和夫 $2 \cdot$ 㐘本統 3 \\ 1正会員 鉄道総合技術研究所 構造物技術研究部（185-8540 東京都国分寺市光町2-8-38） \\ E-mail: togashi.yota.93@rtri.or.jp \\ 2正会員 東京海洋大学教授 大学改革準備室（干108-8477 東京都港区港南4-5-7） \\ E-mail: ktani00@kaiyodai.ac.jp
}

3正会員 横浜国立大学准教授 都市イノベーション研究院（†240-8501 横浜市保土ヶ谷区常盤台79-5）

E-mail: kikumoto@ynu.ac.jp

岩盤は堆積構造や不連続面の影響で異方性を示すことがある。従来, 異方性はサンプリング方向を変え た複数の供試体の試験で調查されてきたが, 労力や時間, コストの面で効率的でない上, 必ずしも異方性 を特定できないという問題があった。 そこで著者らは，一つの試験体で岩盤の異方性を把握できる新しい 原位置試験法を開発した。同試験は異方性岩盤に作製した中空円筒の試験体を所定の拘束圧下でねじりせ ん断する試験であり，試験体の上端面における応力分布を計測することで，異方性を一つの試験体で調査 できる，提案方法によると，最も簡易な異方性構成則の一つである面内等方弾性体に関し，等方圧密時の 主ひずみ方向から異方性の卓越方向を特定でき, 等方圧密時の応力ひずみ関係とねじりせん断時の応力分 布を用いて5つの弾性パラメータを特定できる.

Key Words : rock mass, torsional shear, anisotropy, deformation properties, transversely isotropy

\section{1. はじめに}

岩盤の上に橋脚を建造したり，岩盤を掘削して山岳卜 ンネルを施工する際には，予め岩盤の力学特性を正確に 把握することが重要である，岩盤は層理や節理群，ある いは片理などの不連続面を含み，その力学特性は異方性 を示すため，岩盤構造物の合理的な設計・施工のために は，強度や岡性をスカラー量として評価するだけでなく， 異方性も含めて把握する必要がある。これまでにも，赤 井ら1は超音波速度計測から結晶片岩のヤング率が最大 で約3倍異なることを, Oka et al. ${ }^{2}$ は図-1に示すサンプリ ング方向を変えた戸室石の三軸試験の結果からヤング率 が最大で約2倍異なることを指摘している。このような 岩盤の異方性は，これまで供試体の採取方向を変えた複 数の試験により調査する必要があり, 労力や時間, コス トの面で非効率であった．また，異方性の方向を目視観 察で仮定しているため, 必ずしも異方性の方向や程度が 正しく特定されるとは限らなかった，異方性の方向と程 度を少ない試験回数で特定できれば，岩盤構造物の設 計・施工の合理化を図ることができる.

著者らはこれまで，三軸試験時の異方性岩盤の力学的

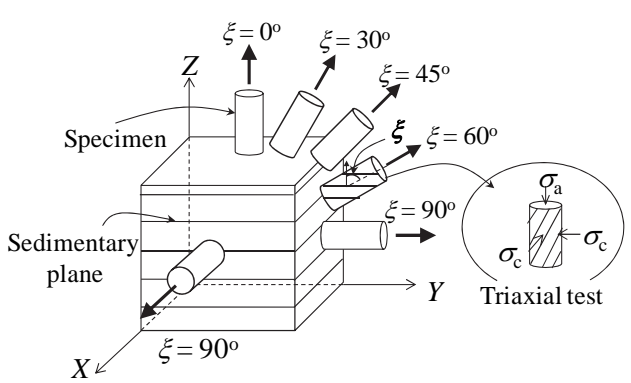

図-1＼cjkstart方向を変えたサンプリングコアの三軸試験 2)



図-2＼cjkstart原位置岩盤ねじりせん断試験 5) 


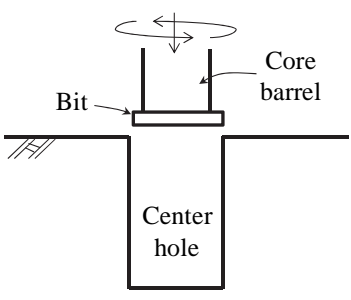

(1) Drilling a center hall

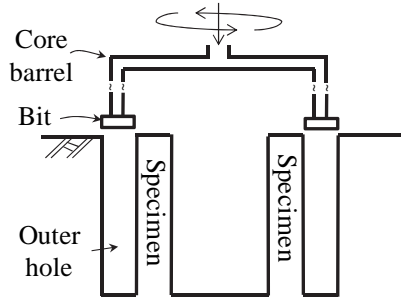

(2) Drilling a outer hall

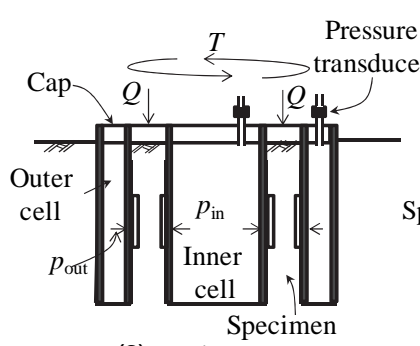

(3) Testing stage

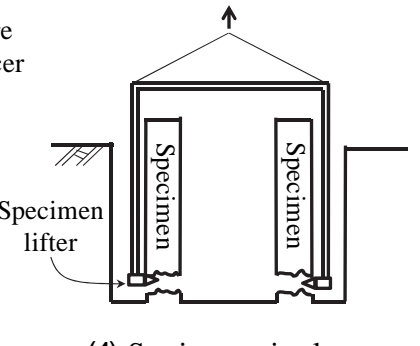

(4) Specimen retrieval stage

図-3 原位置岩盤ねじりせん断試験の手順の)

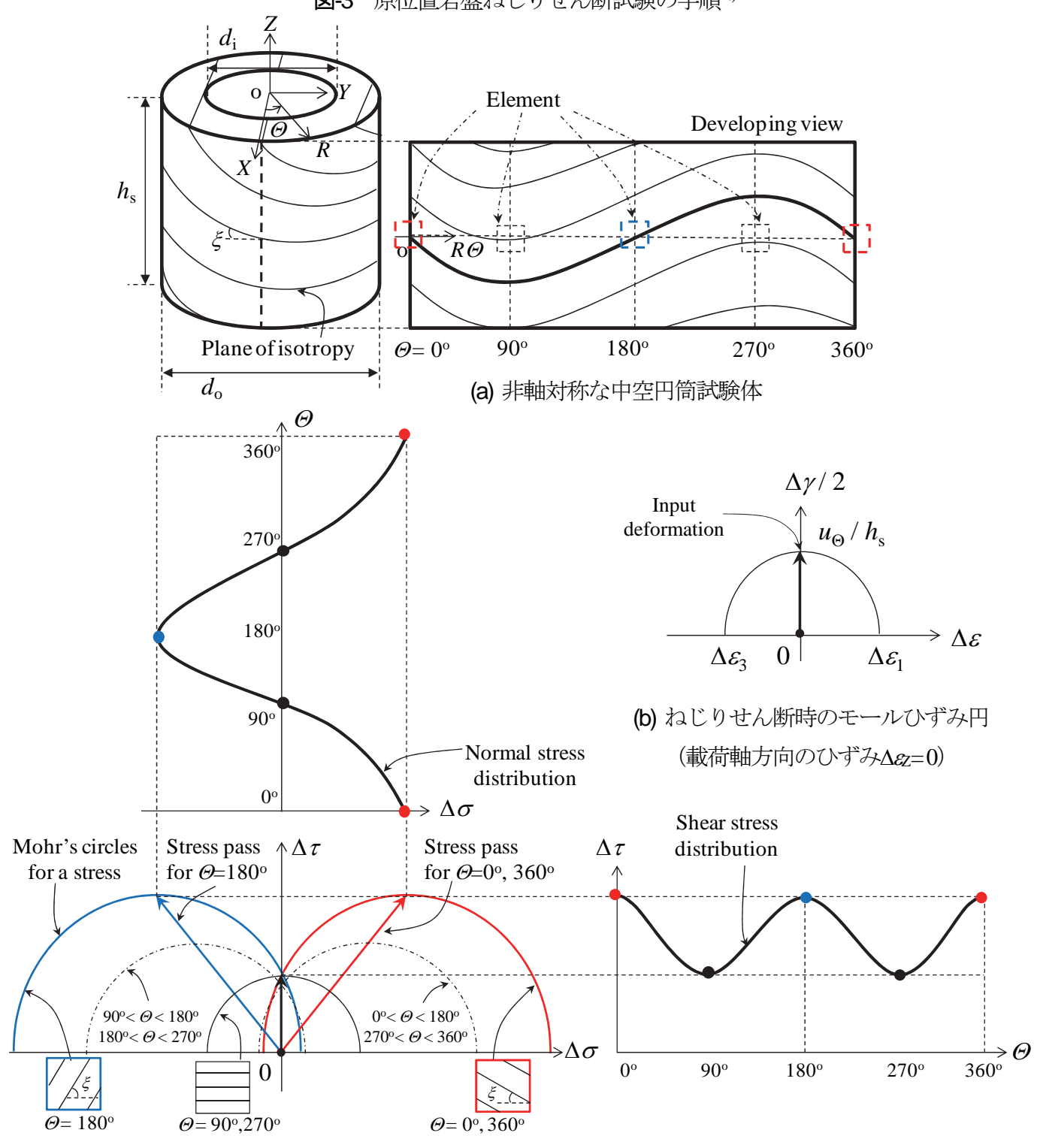

(c) 応答のモール応力円と応力分布の関係

図-4 ねじりせん断時の中空円筒試駼体の応答（平面ひずみ条件）

性質について理論的に検討寸るとともに³)，三軸試験で 異方性を特定する方法4)を提案してきた. 著者らが提案 した三軸試験は一回の試験で異方性を特定できるものの， 岩盤の異方性の程度が小さく等方性材料に近いほど測定 誤差の影響が大きくなることや，主応力方向と異方性の 卓越方向が一致する場合にはせん断剛性率の予測精度が 低下寸ることが課題であった。しかし，これらは主応力
載荷型の試験に起因する課題であり，せん断岡性率を直 接求められる単純せん断モードの応力経路を付加できる 試験により解決できる可能性が高い，このような考えに 基づいて，著者らは図-2に示寸原位置岩盤ねじりせん断 試験を提案した5)。この試験は図-3に示寸ように, 露頭 や試掘抗の岩盤を掘削して中空円筒の試験体を作製し, 所定の拘束圧の下でねじりせん断寸る試験である. 中空 
円筒試験体の掘削は，岡田らが実用化した原位置岩盤三 軸試験のに倣うが，提案試験法は，試験体の上端に設置 した複数の 2 方向ロードセル（分割ロードセル）による 応力分布の計測から，一回の試験で岩盤の力学的異方性 を把握することに特徵がある. 例えば，代表的な異方性 の構成則である面内等方弾性体を想定した中空円筒試験 体は, 図-4(a)のように, 円周 $\Theta$ 方向の各要素で載荷方向 と剛性の等方な面（すなわち不連続面）の方向が異なり， 必ずしも軸対称条件を満たさない，そのため，軸変位を 固定し，ひずみ制御（図-4(b)）でねじりせん断した場合 の試験体内応力を図-4(c)のようにモール円で表すと，円 周方向の各点の要素で異なる応力経路を取り, 試験体内 の応力状態は非一様になることがわかる．このように， 異方性岩盤の場合は，従来の中空ねじりせん断試験で想 定する要素の一様な応答を示さずに, 試験体が図-4(c)の モール円に合わせて描いた円周方向の応力分布のように 非要素として応答する. この非一様な応力分布を円周方 向の分割ロードセルで計測すれば，複数の要素試験を行 うのと同等の構成パラメータの情報を取得できる.

本論文では，原位置岩盤ねじりせん断試験で計測する 応力分布やひずみを用いて，堆積岩などのモデル化を想 定した面内等方弾性体の構成パラメータを1回の試験で 特定する方法を示す，そのために，まず，面内等方弾性 体の構成則からねじりせん断時の中空円筒試験体の挙動 をシミュレートし，試験体の応答を考察する. 次に, こ こで得た計算值をもとに, 面内等方弾性体の構成パラメ 一タを一回の試験で特定する手法を示す，最後に，所定 の測定誤差を設定した条件下での提案手法による異方性 パラメータの特定精度と感度の分析を行う。

\section{2. 面内等方弾性体の中空円筒のねじりせん断時の 変形特性}

ここでは，面内等方弾性体の構成則を用いて図-4で指 摘した中空ねじり試験時の中空円筒試験体の応答を計算 する. 載荷経路は等方圧密と㸚じりせん断の2つを想定 する. 等方圧密時は, 試験体の内外側面と端面に主応力 を一様に与えるため試験体は異方性材料であっても「要 素」の応答を示す，それに対し，軸変位を固定してねじ りせん断を行う際には，与える主ひずみ方向が試験体端 面と $45^{\circ}$ の角度を為し, 円周方向の各点で異方性と主ひ ずみの方向の関係が異なるため, 図-4のように, 円周方 向の各点の要素が異なる応答を示し, 試験体全体として は必ずしも一様でない「非要素」の応答をする．等方性 材料を想定した中空ねじり試験は応力と変形の軸対称性 を想定した試験であるが，軸対称性を満足しない異方性 材料では，応力あるいはひずみの軸対称性も満足されず,



図-5 面内等方弾性体

このような挙動を呈する．本章では，中空ねじり試験に おける要素と非要素の応答を把握するため, 面内等方弾 性体の構成則（忘力とひずみの関係）のシミュレーショ ンを行う、等方圧密時には中空円筒試験体は要素の応答 を, ねじりせん断時には図-4の円周方向 $\Theta$ 各点では要 素として応答するが, 試験体全体では $\Theta$ 方向に非一様に 応答すると想定し計算する.

\section{（1）面内等方弾性体による岩盤のモデル化}

面内等方弾性体とは，図-5に示すように，ある面 $(x$ ’ $y$ 面) では剛性が等方で，その面と垂直な方向 $(z$, 方向）の剛性が異なる異方弾性体である》。層理を含む 堆積岩や, 節理群を持つ火成岩や, 変成岩の変形特性は 面内等方弹性体によってしばしばモデル化される，例え ばGoodmanは節理群を持つ岩盤の弾性挙動8), Amadeiは 堆積岩や変成岩の応答9のモデル化に面内等方弹性体モ デルを用いている.

面内等方弾性体の性質は，等方的な剛性を持つ面の法 線方向と5つの弾性パラメータで規定できる，まず，図5 で $\left(X^{\prime}, Y^{\prime}, Z\right)$ 軸の取り方を説明する. また，等方的な 剛性を持つ面内に $x$ '軸および $y$ '軸をとり, その法線方向 に $z^{\prime}$ 軸をとる、等方的な剛性を持つ $x y^{\prime} y$ '面は, 単位法線 ベクトルや法線ベクトルと $\left(X^{\prime}, Y^{\prime}, Z\right)$ 座標系がなす $3 つ$ の角でも規定できるが，ここでは提案手法の実地盤での

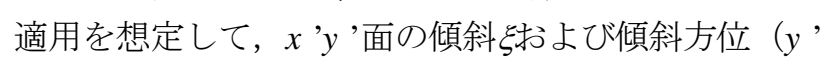

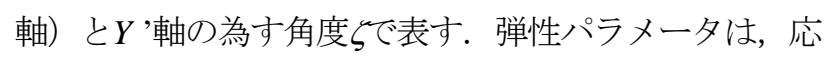
力とひずみの対称性からz'方向のヤング率 $E_{z}$, ポアソン 比 $v^{\prime}$, せん断岡性率 $G_{z} z^{\prime}$ ' $x^{\prime}, y$ ’方向のヤング率 $E_{x}$, ポア


西南北の方位（E, W, S, N) と中空円筒試験体の掘削軸 （すなわち中空ねじり試験のトルク軸Z）に対し，東E 方向を $X$ ’軸方向, 北N方向を $Y$ '軸方向として説明寸る.

\section{（2） 面内等方弾性体の構成則のシミュレーション}

ねじりせん断試験の中空円筒の面内等方弾性体の応答 を求める目的で, 構成則のシミュレーションを行った. 
図-5の $\left(X^{\prime}, Y^{\prime}, Z\right)$ 座標系でZ軸を載荷軸（すなわちトル ク軸）とした座標で計算すると， を含む複雑な応答になる，そのため，本検討では図-6の ように $\zeta=0^{\circ}$ とし $X$ 軸と $x^{\prime}$ 軸を一致させた $(X, Y, Z)$ 座標


じりせん断試験の応力ひずみ関係を示す。載荷軸（Z 軸）に対称な中空円筒試験体を用いることを前提とすれ ば，現実の異方性の方向が $\zeta \neq 0^{\circ}$ の場合でも，応力分布 やひずみなどの計測項目をZ軸周りに-らだけ座標変換し， 求める応力ひずみ関係に合う図-6の座標設定を行えば良 い.

まず，異方性の卓越方向に軸をとった $\left(x^{\prime}, y^{\prime}, z^{\prime}\right)$ 座 標系でコンプライアンステンソル $\hat{C}_{\mathrm{jk} k}$ を考え, その後, 載荷軸方向に軸を設定した $(X, Y, Z)$ 座標系に変換する。 面内等方弾性体の構成関係を式(1)に示寸.

$$
\varepsilon_{\mathrm{ij}}=\hat{C}_{\mathrm{ijkl}} \sigma_{\mathrm{kl}}
$$

\&iłひずみテンソル， 显は応力テンソルである. 式(1)で はi,jがフリーインデックスで', $y^{\prime}, z^{\prime}$ のいずれかを代入す る. $k, l$ はダミーインデックスで $x^{\prime}, y^{\prime}, z^{\prime}$ に対して総和をと る. 2階テンソルの朴と泳はともに圧縮を正とする。 こ こで，単位体積当たりのひずみエネルギーUはの布用い て式(2)のように与えられる.

$$
U=\frac{1}{2} \sigma_{\mathrm{ij}} \hat{C}_{\mathrm{ijkl}} \sigma_{\mathrm{kl}}
$$

$U か ら \hat{C} C_{\mathrm{jk} k}$ を導くと, 式(3)のijとklの可換性が得られる ${ }^{10)}$.

$$
\hat{C}_{\mathrm{ijkl}}=\frac{\partial}{\partial \sigma_{\mathrm{kl}}} \frac{\partial U}{\partial \sigma_{\mathrm{ij}}}=\frac{\partial^{2} U}{\partial \sigma_{\mathrm{kl}} \partial \sigma_{\mathrm{ij}}}=\frac{\partial}{\partial \sigma_{\mathrm{ij}}} \frac{\partial U}{\partial \sigma_{\mathrm{kl}}}=\hat{C}_{\mathrm{klij}}
$$

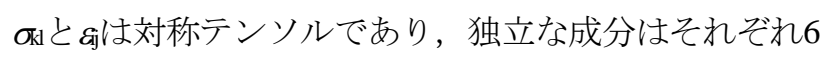
つである. よって, 式(3)と併せて $\hat{C_{\mathrm{jkk}}}$ の添字は式(4)の可 換性をもつことがわかる.

$$
\hat{C}_{\mathrm{ijkl}}=\hat{C}_{\mathrm{jikl}}=\hat{C}_{\mathrm{ijlk}}=\hat{C}_{\mathrm{klij}}
$$

式(4)を考慮すると，4階テンソル $\hat{C}_{\mathrm{j} k \mathrm{kl}}$ の独立な成分は21個 となり, 非零の成分を式(5)で表す》。

$$
\begin{aligned}
& \hat{C}_{x^{\prime} x^{\prime} x^{\prime} x^{\prime}}=\hat{C}_{y^{\prime} y^{\prime} y^{\prime} y^{\prime}}=\frac{1}{E_{x^{\prime}}}, \hat{C}_{z^{\prime} z^{\prime} z^{\prime}}=\frac{1}{E_{z^{\prime}}} \\
& \hat{C}_{x^{\prime} x^{\prime} y^{\prime} y^{\prime}}=-\frac{v_{x^{\prime}}}{E_{x^{\prime}}}, \hat{C}_{x^{\prime} x^{\prime} z^{\prime} z^{\prime}}=\hat{C}_{y^{\prime} y^{\prime} z^{\prime} z^{\prime}}=-\frac{v_{z^{\prime}}}{E_{z^{\prime}}} \\
& \hat{C}_{y^{\prime} z^{\prime} y^{\prime} z^{\prime}}=\frac{1}{G_{z^{\prime}}}, \hat{C}_{x^{\prime} y^{\prime} y^{\prime} y^{\prime}}=2\left(\hat{C}_{x^{\prime} x^{\prime} x^{\prime} x^{\prime}}-\hat{C}_{x^{\prime} x^{\prime} y^{\prime} y^{\prime}}\right)
\end{aligned}
$$

得られた $\hat{C}_{\mathrm{jk} k}$ の成分を, 式(6)により $(X, Y, Z)$ 座標系に座 標変換する ${ }^{11)}$.

$$
C_{\mathrm{mnpq}}=\hat{C}_{\mathrm{ijkl}} l_{\mathrm{im}} l_{\mathrm{jn}} l_{\mathrm{kp}} l_{\mathrm{lq}}
$$

$m, n, p, q$ はリーインデックスで $X, Y, Z$ のいずれかを代入

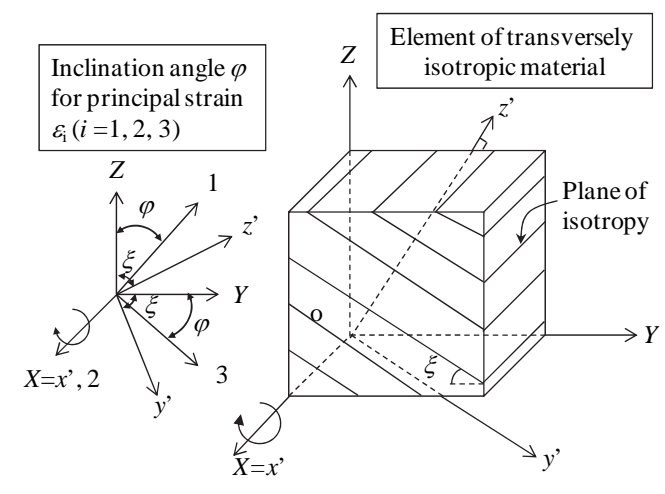

図-6 本研究での座標設定

する. $C_{\mathrm{mppq}}$ は $\hat{C}_{\mathrm{jkk}}$ と同様に, 式(4)で示した添字の可換性 を持つ. $l_{\mathrm{j}}$ はX軸周りの回転を表す2階のテンソルで，成 分を行列Iで表すと式(7)になる11).

$$
\mathbf{I}=\left(\begin{array}{lll}
l_{\mathrm{Xx}} & l_{\mathrm{Xy}^{\prime}} & l_{\mathrm{Xz}} \\
l_{\mathrm{YX}} & l_{\mathrm{Yy}^{\prime}} & l_{\mathrm{Yz}^{\prime}} \\
l_{\mathrm{ZX}} & l_{\mathrm{Zy^{ \prime }}} & l_{\mathrm{Zz}}
\end{array}\right)=\left(\begin{array}{ccc}
1 & 0 & 0 \\
0 & \cos \xi & -\sin \xi \\
0 & \sin \xi & \cos \xi
\end{array}\right)
$$

なお，載荷軸（ $Z$ 軸）方向と $z^{\prime}$ 軸が一致するとき（ $\xi=$ $\left.0^{\circ}\right)$, 行列 は単位行列となり, $C_{\mathrm{j} k}$ の成分は $\left(x^{\prime}, y^{\prime}, z^{\prime}\right)$ 座標系と同じになる.

以上より，面内等方弾性体の構成関係は式(8)になる.

$$
\varepsilon_{\mathrm{ij}}=C_{\mathrm{ijkl}} \sigma_{\mathrm{kl}}
$$

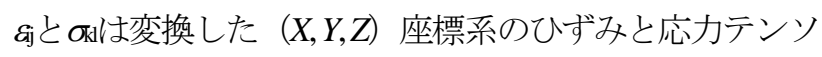
ルの成分であり $, i, j, k, 1$ イイン゙ックスには $X, Y, Z$ を用い る.

\section{（3）中空ねじり試験と解析条件}

本研究で提案する図-2の原位置岩盤ねじりせん断試験 では，(2)の議論と同様に計測項目をZ軸周りに-らだけ座 標変換し, 図-6の $(X, Y, Z)$ 座標に座標変換した上で等 方圧密と㸚じりせん断の2つの載荷条件を付与する。等 方圧密時には試験体の上下端面と内外側面に等方な主応 力を与えるため, 試験体は要素として挙動する. このと き，式(9)の条件を付与する.

$$
\begin{aligned}
& \sigma_{\mathrm{XX}}=\sigma_{\mathrm{YY}}=\sigma_{\mathrm{ZZ}}=\sigma_{\mathrm{c}} \\
& \sigma_{\mathrm{XY}}=\sigma_{\mathrm{ZY}}=\sigma_{\mathrm{ZX}}=0
\end{aligned}
$$

のは等方圧密応力である，なお，式(9)の条件を満たすた めには，試験体の上端には端面摩擦を除去する機構を備 えておくことが望ましい.

一方，ねじりせん断時には円周方向にせん断ひずみを 与える応力経路を考える. 図-4(b)のように主ひずみ方向 は端面から $45^{\circ}$ 傾斜しており, 試験体全体では非要素の 応答を示す。このとき, 等方圧密過程で式(7)で与えた 応力経路に加え, 通常の中空ねじり試験と同様に載荷軸 
方向の変形を拘束しながらねじりせん断する.この条件 を式(10)のように付与する.

$$
\begin{aligned}
& \Delta \varepsilon_{\mathrm{ZX}}=-\Delta \varepsilon_{\mathrm{Z} \Theta} \sin \Theta \\
& \Delta \varepsilon_{\mathrm{ZY}}=\Delta \varepsilon_{\mathrm{Z \Theta}} \cos \Theta \\
& \Delta \sigma_{\mathrm{XX}}=\Delta \sigma_{\mathrm{YY}}=0 \\
& \Delta \varepsilon_{\mathrm{ZZ}}=\Delta \varepsilon_{\mathrm{XY}}=0
\end{aligned}
$$

$\Delta \varepsilon z_{\Theta}$ は円周方向のせん断ひずみ増分である. 面内等方弾 性体の応力ひずみ関係は線形であるため，供試体内の応 力状態は初期応力の設定に依らず，式(7)と(8)のように 等方圧密とねじりせん断の応力変化のみを考える.

\section{（4）ねじりせん断試験時の中空円筒試験体の応力とひ ずみの特性}

面内等方弾性体に関し，(2)の条件で原位置岩盤ねじ りせん断試験を実施したときに得られる応力とひずみの 特性を検討する．図-7に等方圧密時の応力とひずみの理 論解を示す。これは，ヤング率の異方性が最大約2倍の, 面内等方性の弾性パラメータを $\left(E_{z}, v_{z}, G_{z}, E_{x}, w_{x}\right)=$

(1000MPa, 0.3, 289MPa, 490MPa, 0.21) と設定した例で，

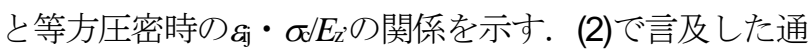
り, 等方圧密時には, 内圧, 外圧および軸圧縮応力が等 しい応力状態となるため試験体の変形は円周方向に依存 せずに要素の挙動をするとして計算を行った. 同図から は応答のひずみが依存してせん断ひずみ $E L$ 発生す ることがわかる．ただし， $\xi=0^{\circ} の$ 場合はz軸対称に変形


合は対称軸が $y^{\prime}$ 軸となるが同様に軸対称に変形する. 同 様の弾性パラメータに対し, 図-8(a)は等方圧密時の主ひ ずみ $\varepsilon \cdot \sigma / E_{z^{\prime}}(i=1,2,3)$ と $\xi$ の関係を示寸. なお，構成 式(8)が客観性の原理を満たすことから，ねじりせん断 時のように特定の方向からの載荷経路と異なり, 等方圧 密時には試験体に等方な応力を作用させるため， $\boldsymbol{a}$ は $\boldsymbol{\xi}$ に依らず一定值となる．図-8(b)に等方圧密時の主ひずみ 軸の傾斜 $\varphi$ と $\xi$ 関係を示す。この条件では，等方圧密 時には主ひずみ軸と異方性の方向が一致するため，ひず みテンソル6成分の計測を行えば異方性の方向 $(\zeta, \xi)$ が 得られることがわかった。

次に, ねじりせん断時には, 式(10)の条件を構成式(8) に代入した上で, $(X, Y, Z)$ 座標の応力を次式(11)で円筒 座標系 $(R, \Theta, Z)$ に変換して応力ひずみ関係を得る.

$$
\sigma_{\mathrm{ij}}=\sigma_{\mathrm{mn}} m_{\mathrm{im}} m_{\mathrm{jn}}
$$

$i, j$ はフリーインデックスでR, $\Theta, Z$ Z $m, n$ はダミーイン デックスで $X, Y, Z$ を代入する． $m_{\mathrm{ij}}$ はZ軸周りの回転を表す 2階テンソルで，成分を行列 $\mathbf{m}$ で表すと式(12)になる.

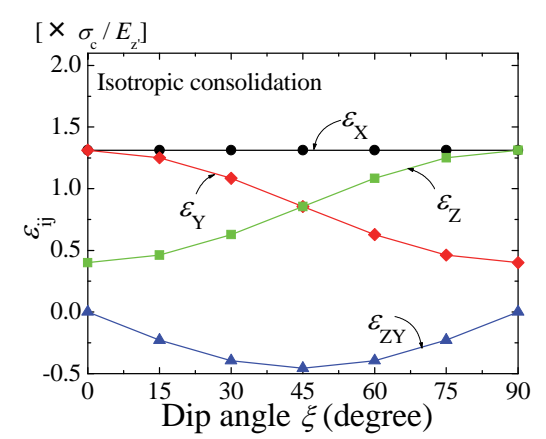

図-7 等方圧密時のひずみテンソル



(a) 等方圧密時の 主ひずみの応

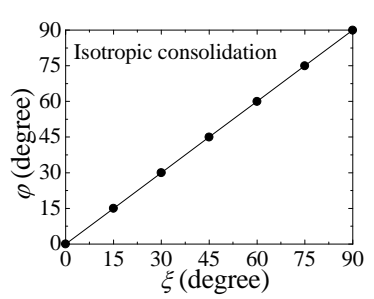

(b) 主ひずみ軸の傾斜 $\varphi$ と朳関係
図-8 等方圧密時の主ひずみの応答

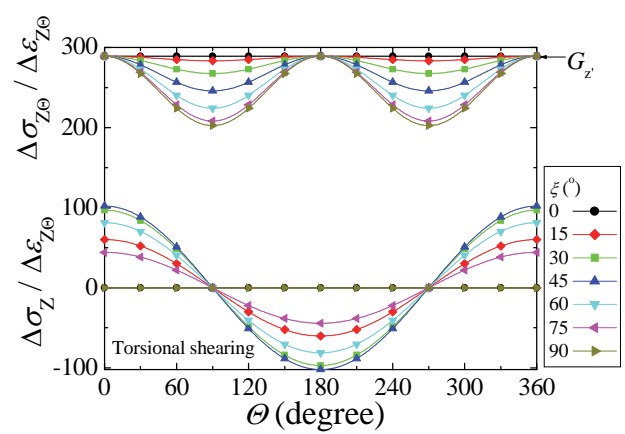

図-9 ねじりせん断時の応力分布

$$
\mathbf{m}=\left(\begin{array}{lll}
m_{\mathrm{XR}} & m_{\mathrm{X} \Theta} & m_{\mathrm{XZ}} \\
m_{\mathrm{YR}} & m_{\mathrm{Y} \Theta} & m_{\mathrm{YZ}} \\
m_{\mathrm{ZR}} & m_{\mathrm{Z} \Theta} & m_{\mathrm{ZZ}}
\end{array}\right)=\left(\begin{array}{ccc}
\cos \Theta & -\sin \Theta & 0 \\
\sin \Theta & \cos \Theta & 0 \\
0 & 0 & 1
\end{array}\right)
$$

等方圧密時と同様の構成パラメータで，ねじりせん断 時の応力とひずみの関係を, 図-9に $\xi$ 毎に表す。このよ うに，ねじりせん断時には試験体が必ずしも軸対称条件 を満たさないため, 円周方向 $\Theta$ に直応力とせん断応力が 分布する. なお， $\xi=0^{\circ}$ の場合は試験体が軸対称条件を満 たすため応力は一様になる. また， $\xi=90^{\circ} の$ 場合は直応 力に対し試験体が軸対称となるため $\Delta \sigma は$ 発生しないが, 円周方向のせん断応力に対しては軸対称な載荷条件にな らないため $\Delta \sigma \circlearrowright か ゙$ 発生する. 次章では，ここで計算した 応力とひずみの関係を用いて，原位置岩盤ねじりせん断 試験の計測結果から異方性を特定する手法を提案する. 


\section{3. 一回の試行で異方性岩盤の変形特性を特定す る方法の提案}

面内等方弾性体に関し，2章で求めた中空ねじり試験 の理論解をもとに，等方圧密とねじりせん断の載荷経路 を想定した原位置岩盤ねじりせん断試験から，構成パラ メータを取得する方法を説明する.

\section{(1) 等方圧密時のひずみテンソルを計測する手法}

2章の(4)で示したように，等方圧密時の主ひずみ方向 が取得できれば，異方性の方向を特定できる.すなわち， ひずみテンソルの独立な6成分を計測すれば主ひずみと その方向を取得できるので，例えば試験体側面の図-10 に示す位置と方向に6枚のひずみゲージを設置し，ひず みテンソルを計測する ${ }^{12)} \cdot p$ 番目のひずみゲージで計測 した直ひずみを虫とし，ゲージを貼る方向の単位べクト

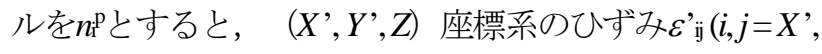
$\left.Y^{\prime}, Z\right)$ と $x^{\mathrm{p}}$ は， $x^{\mathrm{p}}=n_{\mathrm{i}}^{\mathrm{p}} \mathcal{E}_{\mathrm{i}} n_{\mathrm{j}}^{\mathrm{p}}$ で関係づけられる ${ }^{12)} . こ こ か ら \varepsilon^{\prime}$ を式(13)のように導く.

$\left(\begin{array}{c}\varepsilon_{\mathrm{X}^{\prime}}^{\prime} \\ \varepsilon_{\mathrm{Y}^{\prime}}^{\prime} \\ \varepsilon_{\mathrm{Z}}^{\prime} \\ 2 \varepsilon_{\mathrm{X}^{\prime} \mathrm{Y}^{\prime}}^{\prime} \\ 2 \varepsilon_{\mathrm{Y}^{\prime} \mathrm{Z}} \\ 2 \varepsilon_{\mathrm{ZX}}^{\prime}\end{array}\right)=\left(\begin{array}{cccccc}0 & 0 & 1 & -1 & 1 & 0 \\ 0 & 1 & -1 & 1 & -1 & 1 \\ 0 & 0 & 0 & 1 & 0 & 0 \\ 0 & -1 & 0 & 0 & 0 & 1 \\ -2.31 & 0.58 & -0.58 & 2.31 & -0.58 & 0.58 \\ 0 & 0 & 0.58 & 1.15 & -1.73 & 0\end{array}\right)\left(\begin{array}{c}x^{1} \\ x^{2} \\ x^{3} \\ x^{4} \\ x^{5} \\ x^{6}\end{array}\right)$

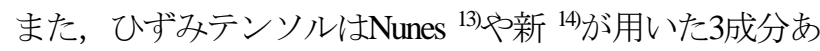
るいは4成分のロゼッタゲージを複数枚用いる方法でも 取得できるが，独立な6成分の取得にロゼッタゲージが3 枚以上も必要になるため, 効率的でない. ところで, 提 案手法はひずみゲージでの変形計測に適した剛性を有す る岩盤に対して6成分の直ひずみを計測し，計測值から ひずみテンソルを算出するが，砂や粘土など岡性が低い 土ではひずみゲージの使用が難しい，このような低剛性 材料に対しては, 例えばGaspame et al. ${ }^{15}$ がLondon clayに対 しベンダーエレメントでせん断岡性率を計測できる中空 ねじり試験を行って変形異方性を取得した結果を示して いる．また，Nishimura16は粘土を対象としてベンダーエ レメントと渦電流式変位計を複数配置した三軸試験によ る異方性取得法を提案している. しかし，これら既存の 低剛性材料の異方性特定方法では，ひずみ成分を波動伝 播速度の計測などにより補う手法がいくつか提案されて いるものの，ひずみテンソルを直接的に算定する方法は ない.このため本提案手法は剛性が高い岩盤への適用を 想定しているが，今後の検討により低剛性材料でもひず みテンソルの算出が可能になれば，本提案手法の適用範 囲を拡大することは十分に可能であると考えられる.



図-10 ひずみゲージの貼り方（矢印は計測方向） ${ }^{12)}$

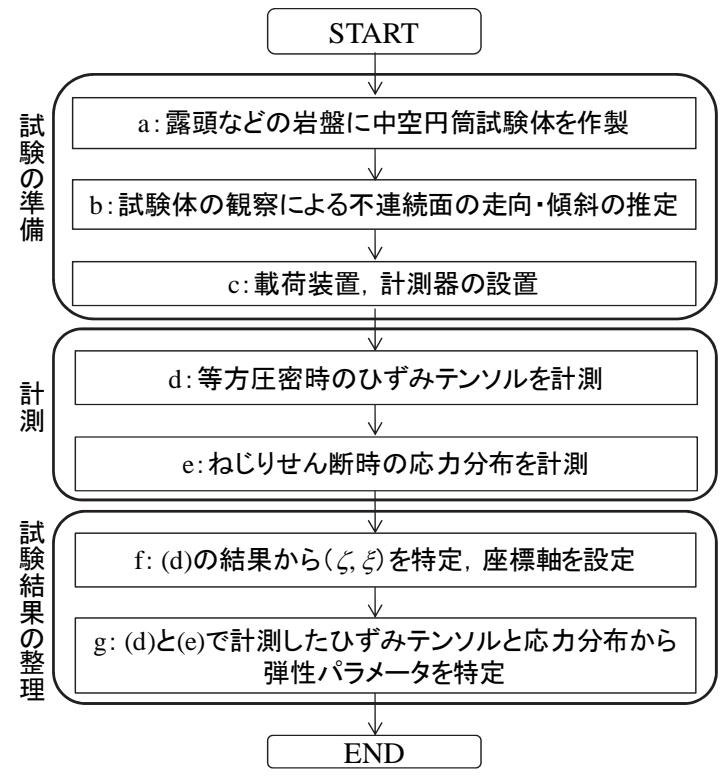

図-11 面内等方弾性体の構成パラメータの取得方法 ${ }^{17}$

\section{（2）面内等方弾性体の構成パラメータの特定方法}

原位置岩盤ねじりせん断試験で面内等方弾性体の構成 パラメータを特定する手法を図-11に提案する17。 まず, 岩盤を掘削して中空円筒試験体を作製し (a), 目視観察 を行って，岡性が等方と推定される面（すなわち不連続 面）の方向（走向と傾斜）を推定する (b). このとき， 目視観察で得られる走向と傾斜は図-5で定義した（ ）と必ずしも一致しないことに注意する. 次に, 東西 南北の方位（すなわち図-5の $\left(X^{\prime}, Y^{\prime}, Z\right)$ 座標系の方 向）とサンプリング方向（すなわち載荷軸Z方向）の関 係を確認し，ひずみゲージなどの計測機器を設置する (c).ひずみゲージは前述した図-10の設置方法などに従 う。次に，等方圧密 (d)，衿じりせん断 (e)を行い，応力 とひずみの計測を行う.

この特定方法は, 異方線形弾性論から導かれるため, 各載荷はひずみレベルを約 $10^{4}$ 以下の弾性域で行うこと 


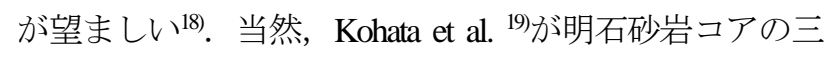
軸試験で行ったように，段階的に応力あるいはひずみレ ベルを増減させ岡性の変化を計測することもできる，次

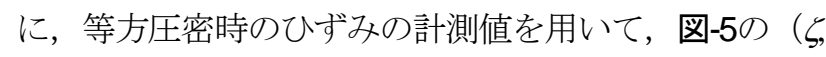

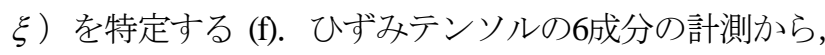
$\left(X^{\prime}, Y^{\prime}, Z\right)$ 座標系での等方圧密時のひずみテンソル $\boldsymbol{\varepsilon}^{\prime}$ は式(14)で表される.

$$
\boldsymbol{\varepsilon}^{\prime}=\left(\begin{array}{ccc}
\varepsilon_{\mathrm{X}^{\prime}} & \varepsilon_{\mathrm{X}^{\prime} \mathrm{Y}^{\prime}} & \varepsilon_{\mathrm{X}^{\prime} \mathrm{Z}} \\
& \varepsilon_{\mathrm{Y}^{\prime}} & \varepsilon_{\mathrm{Y}^{\prime} \mathrm{Z}} \\
\text { sym. } & & \varepsilon_{\mathrm{Z}}
\end{array}\right)
$$

ぞを式(15)で対角化して主ひずみを求める.

$$
\mathbf{e}^{\mathrm{T}} \boldsymbol{\varepsilon}^{\prime} \mathbf{e}=\left(\begin{array}{ccc}
\varepsilon_{1} & 0 & 0 \\
& \varepsilon_{2} & 0 \\
\text { sym. } & & \varepsilon_{3}
\end{array}\right)
$$

（1,2,3）は主ひずみの軸方向を表す座標系である．図-6 では中間主ひずみ軸が $X$ 軸と一致しているが，この段階 で $(1,2,3)$ と $(X, Y, Z)$ 座標系の各軸が必ずしも一致す る必要はない．式(15)の $\mathbf{e}$ は，（1, 2, 3）座標系の主ひず みの各軸方向の基底べクトルを $\mathbf{e}^{1}, \mathbf{e}^{2}, \mathbf{e}^{3}$ とすると, $\mathbf{e}=\left(\mathbf{e}^{1}\right.$, $\left.\mathbf{e}^{2}, \mathbf{e}^{3}\right)$ と表すことができる．なお， $\mathbf{e}^{\mathrm{i}}$ は縦ベクトルで並心゙ eを構成する. 以上より，式(16)から式(15)の主ひずみの 単位方向行列这求める.

$$
\mathbf{e}=\left(\begin{array}{lll}
e_{11} & e_{12} & e_{13} \\
e_{21} & e_{22} & e_{23} \\
e_{31} & e_{32} & e_{33}
\end{array}\right)=\left(\begin{array}{ccc}
\cos \zeta & \sin \zeta & 0 \\
-\cos \xi \sin \zeta & \cos \xi \cos \zeta & \sin \xi \\
\sin \xi \cos \zeta & -\sin \xi \cos \zeta & \cos \xi
\end{array}\right)
$$

等方圧密時には，異方性の方向 $\left(x^{\prime}, y^{\prime}, z^{\prime}\right)$ と主ひずみ方 向（1, 2, 3） が一致するため, $(\zeta, \xi)$ を変数とする三角

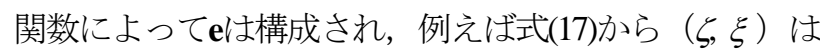
特定できる.

$$
\begin{aligned}
& \xi=\cos ^{-1}\left(e_{33}\right) \\
& \zeta=\cos ^{-1}\left(e_{11}\right)
\end{aligned}
$$

単位方向行列 $\mathbf{e}$ 独立な成分は6つあり，式(17)以外にも，

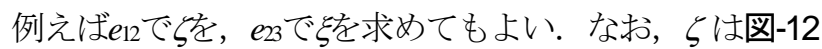
のように，ねじりせん断時の直応力増分 $\Delta \sigma$ とせん断応 力増分 $\Delta \sigma \Theta$ が最大となる $\Theta$ 位置から求めることもでき る.ここで， $Y$ 軸から時計周りに $\zeta$ の位置にY軸を設置し， 直交座標系 $(X, Y, Z)$ を設定する。 この操作でX軸と $x$ 軸 は一致し, 式(6)で設定したコンプライアンステンソル に準じた座標となる．なお，(b) の目視観察で得た走向 と傾斜との整合をこの時点で確認できる. また, 算出し た弾性解の座標系と試験結果を合わせるため，式(14)の ひずタテンソルを, 式(18)で $\left(X^{\prime}, Y^{\prime}, Z\right)$ から $(X, Y, Z)$ に座 標変換する.

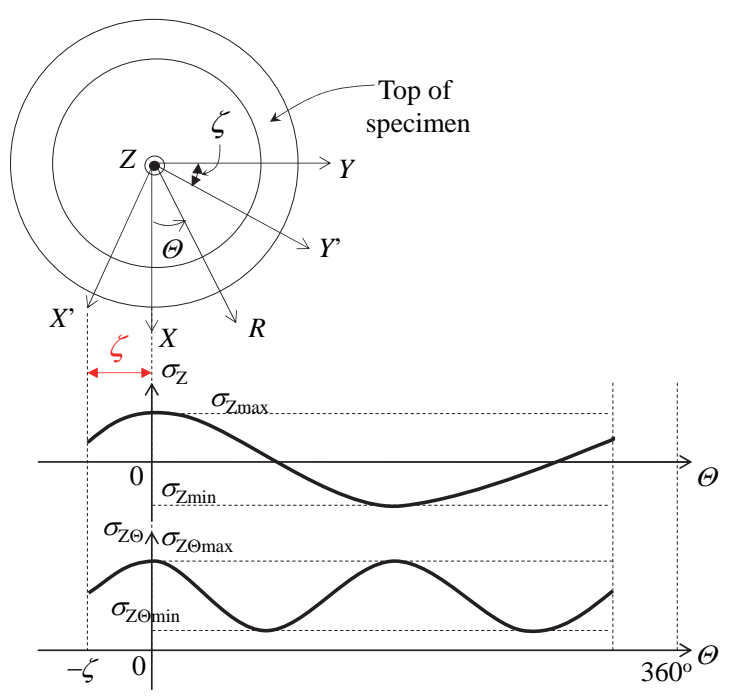

図-12 応力分布の最大・最小值と $(X, Y, Z)$ 座標系の関係



図-13 等方性と異方性の判定

$\left(\begin{array}{ccc}\cos \zeta & \sin \zeta & 0 \\ -\sin \zeta & \cos \zeta & 0 \\ 0 & 0 & 1\end{array}\right) \varepsilon^{\prime}\left(\begin{array}{ccc}\cos \zeta & -\sin \zeta & 0 \\ \sin \zeta & \cos \zeta & 0 \\ 0 & 0 & 1\end{array}\right)=\left(\begin{array}{ccc}\varepsilon_{\mathrm{X}} & \varepsilon_{\mathrm{XY}} & \varepsilon_{\mathrm{ZX}} \\ & \varepsilon_{\mathrm{Y}} & \varepsilon_{\mathrm{ZY}} \\ \text { sym. } & & \varepsilon_{\mathrm{Z}}\end{array}\right)$

以上で得た等方圧密時の応答から，図-13に示すように 試験岩盤が等方的か異方的な変形特性を持つかが判定で きる．まず，等方性の場合は変形特性が方向性を持たな いため $\xi \neq 0^{\circ}, 90^{\circ}$ が得られれば異方性を持つと判断できる。 $\xi=0^{\circ}, 90^{\circ}$ の場合は，異方性と等方性の両方の可能性があ るが，直ひずみの応答が等方 $(\varepsilon \mathrm{x}=\mathscr{g x}=\varepsilon \mathrm{Z})$ で，せん断ひ ずみがゼロであれば等方性であり，それ以外は異方性を 持つ岩盤と判断できる.

次に，(d) と (e)で計測した応力とひずみを用いて，弾 性パラメータを定める (g). 2章で計算した等方圧密時の 応力とひずみの関係を式(19)に示す.

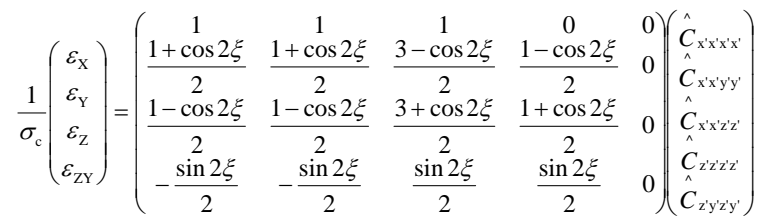


ひずみテンソルの成分は式(18)から得たものを，のは載 荷軸方向のロードセルあるいはセル圧計で計測した值を 式(19)の左辺に代入する.

同様に，ねじりせん断時の応力とひずみの関係を式 (20)で下記に示す. 原位置岩盤ねじりせん断試験の試験 体は，図-2のように載荷の反力を得るため試験体下端は 岩盤と連続しているが，本検討ではNunes ${ }^{13)}$ がLekhnitskii et al. ${ }^{20)}$ の解析法を参考に求めたCSIR三軸セルの2軸圧縮時 の応力ひず夕関係と同様，図-4に示す中空円筒に関して ねじりせん断時の3次元の応力とひずみの関係を求めた 直方向とせん断方向の両方で，応力とひずみの関係は円 周方向 $\Theta$ 関数で表される.ここでは, 式(20)のコンプ ライアンステンソル成分, 寸なわち面内等方弾性体の弾 性パラメータを合理的に求めることを考え，応答の直応 力とせん断応力が最大・最少となる計測項目に着目して, $\Theta=0^{\circ}$ の位置の直応力増分とせん断応力増分 $(\Delta \sigma \mathrm{Za} 0$,

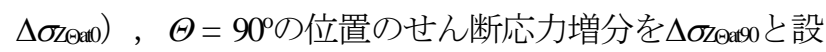
定する. これらの計測点での応力とひずみの関係を下記 の式(21)に示す. コンプライアンステンソルの成分 $\hat{C}_{z^{\prime} y^{\prime} z^{\prime}}$

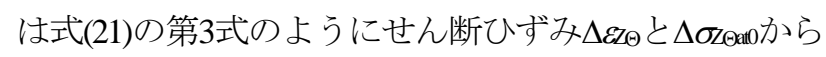
直接求められることがわかる。なお， $\left(\Delta \sigma_{\text {Zal }}, \Delta \sigma\right.$ て

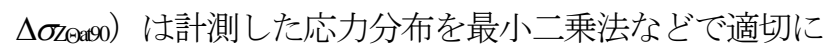
フィッティングした後に值を定めた上で，せん断ひずみ

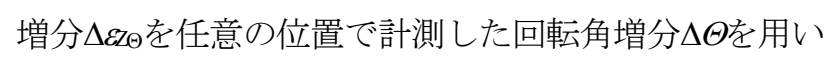
て式(22)のように求め式(21)に代入する.

$$
\Delta \varepsilon_{\mathrm{Z} \Theta}=\frac{\left(d_{\mathrm{o}}+d_{\mathrm{i}}\right) \Delta \Theta}{8 h_{\mathrm{s}}}
$$

$d_{0}$ とdi， $h_{s}$ は図-4(a)に示した試験体の外径と内径，高さで ある. 応力分布を正確に把握するにはロードセルの分割 数が多い方が好ましいが，この手法では $\Theta$ 方向に90㷰倠れ

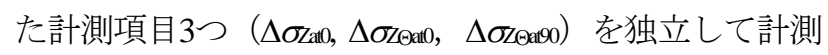
できれば良く, すなわち図-4の $X Y$ 面での試験体中心

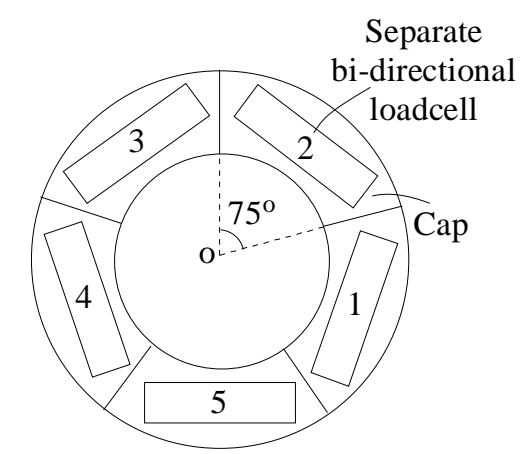

図-14 5分割 2方向ロードセルの配置

（o）から $90^{\circ}$ 以下の角度で2方向ロードセルが隣接すれ ばよい，従って，図-14に示すように最低限5等分割すれ ば求める構成パラメータに対して十分である.

次に，計測した応力とひずみの関係のデータから，最 小二乗法により式(23)で弾性パラメータを特定する.

$$
\mathbf{C}=\left(\mathbf{A}^{\mathrm{T}} \mathbf{A}\right)^{-1} \mathbf{A}^{\mathrm{T}} \mathbf{k}
$$

kは式(19), (21)の計測した応力あるいは応力分布とひずみ 関係から計算される6成分のベクトルで，各成分を式(24) で表す。

$$
\begin{aligned}
& k_{1}=\varepsilon_{\mathrm{x}} / \sigma_{\mathrm{c}}, k_{2}=\varepsilon_{\mathrm{Y}} / \sigma_{\mathrm{c}}, k_{3}=\varepsilon_{\mathrm{z}} / \sigma_{\mathrm{c}}, k_{4}=\varepsilon_{\mathrm{ZY}} / \sigma_{\mathrm{c}} \\
& k_{5}=\frac{\sin 2 \xi}{2}\left(\frac{\sin 2 \xi}{2} \Delta \sigma_{\mathrm{Zat} 0} \hat{C}_{z^{\prime} \mathrm{y}^{\prime} \mathrm{y}^{\prime} \mathrm{y}^{\prime}}+\Delta \varepsilon_{\mathrm{Z} \Theta} \cos 2 \xi\right) \\
& k_{6}=\frac{\Delta \varepsilon_{\mathrm{Z} \Theta}}{\Delta \sigma_{\mathrm{Z} \Theta a \mathrm{a} 90}}-\frac{1+\cos 2 \xi}{2} \hat{C}_{\mathrm{z}^{\prime} \mathrm{y}^{\prime} \mathrm{y}^{\prime}}
\end{aligned}
$$


れるベクトルで, 次ページの式(25)に示す. 式(21)より $\hat{C}$ $z^{\prime} y^{\prime} y^{\prime}$ は計測值から直接に求められるため, 残りの $\hat{C_{\mathrm{j} k}}$ の成 分Cを式(25)で求める. 求めたCを用い式(26)から面内等 方弾性体を仮定した5つの弾性パラメータを決定する.

$$
\begin{aligned}
& \Delta \sigma_{\mathrm{z}}=-\frac{2\left(-\sin ^{3} \xi \cos \xi+\left(\sin ^{3} \xi \cos \xi-\sin \xi \cos ^{3} \xi\right) \hat{C}_{\mathrm{x}^{\prime} \mathrm{x}^{\prime} \mathrm{z}^{\prime} \mathrm{z}^{\prime}}+\sin \xi \cos ^{3} \xi \hat{C}_{\mathrm{z}^{\prime} \mathrm{z}^{\prime} \mathrm{z}^{\prime}}+\frac{1}{2}\left(\sin ^{3} \xi \cos \xi-\sin \xi \cos ^{3} \xi\right) \hat{C}_{\mathrm{z}^{\prime} \mathrm{y}^{\prime} \mathrm{z}^{\prime} \mathrm{y}^{\prime}}\right)}{\sin ^{4} \xi \hat{C}_{\mathrm{x}^{\prime} \mathrm{x}^{\prime} \mathrm{x}^{\prime} \mathrm{x}^{\prime}}+2 \sin ^{2} \xi \cos ^{2} \xi \hat{C}_{\mathrm{x}^{\prime} \mathrm{x}^{\prime} \mathrm{z}^{\prime}}+\cos ^{4} \xi \hat{C}_{\mathrm{z}^{\prime} \mathrm{z}^{\prime} \mathrm{z}^{\prime} \mathrm{z}^{\prime}}+\sin ^{2} \xi \cos ^{2} \xi \hat{C}_{\mathrm{z}^{\prime} \mathrm{y}^{\prime} \mathrm{y}^{\prime} \mathrm{y}^{\prime}}} \frac{\Delta \varepsilon_{\mathrm{z} \Theta} \cos \Theta}{\hat{C}_{\mathrm{z}^{\prime} \mathrm{y}^{\prime} \mathrm{y}^{\prime}}}, \\
& \Delta \sigma_{\mathrm{z} \Theta}=\sin ^{2} \Theta\left(\frac{1}{\hat{C}_{\mathrm{x}^{\prime} \mathrm{y}^{\prime} \mathrm{x}^{\prime} \mathrm{y}^{\prime}}} \sin ^{2} \xi+\frac{1}{\hat{C}_{\mathrm{z}^{\prime} \mathrm{y}^{\prime} \mathrm{z}^{\prime} \mathrm{y}^{\prime}}} \cos ^{2} \xi\right) \Delta \varepsilon_{\mathrm{z} \Theta}+\cos ^{2} \Theta \frac{\Delta \varepsilon_{\mathrm{z} \Theta}}{\hat{C}_{\mathrm{z}^{\prime} \mathrm{y}^{\prime} \mathrm{z}^{\prime} \mathrm{y}^{\prime}}}
\end{aligned}
$$

$$
\begin{aligned}
& \frac{\sin 2 \xi}{2}\left(\frac{\sin 2 \xi}{2} \Delta \sigma_{\mathrm{zat} 0} \hat{C}_{z^{\prime} y^{\prime} z^{\prime} y^{\prime}}+\Delta \varepsilon_{\mathrm{z} \Theta} \cos 2 \xi\right)
\end{aligned}
$$

$$
\frac{\Delta \varepsilon_{\mathrm{z} \Theta}}{\Delta \sigma_{\mathrm{z} \Theta \mathrm{at} 90}}-\frac{1+\cos 2 \xi}{2} \hat{C}_{\mathrm{z}^{\prime} \mathrm{y}^{\prime} \mathrm{z}^{\prime} \mathrm{y}^{\prime}}=\frac{4}{1-\cos 2 \xi} \hat{C}_{\mathrm{x}^{\prime} \mathrm{x}^{\prime} \mathrm{x}^{\prime} \mathrm{x}^{\prime}}+\frac{4}{\cos 2 \xi-1} \hat{C}_{\mathrm{x}^{\prime} \mathrm{x}^{\prime} \mathrm{y}^{\prime} \mathrm{y}^{\prime}}, \quad \hat{C}_{\mathrm{z}^{\prime} \mathrm{y}^{\prime} \mathrm{y}^{\prime} \mathrm{y}^{\prime}}=\frac{\Delta \varepsilon_{\mathrm{Z} \Theta}}{\Delta \sigma_{\mathrm{z} \Theta \mathrm{at} 0}}
$$ 




$$
\begin{gathered}
E_{z^{\prime}}=\frac{1}{\hat{C}_{z^{\prime} z^{\prime} z^{\prime} z^{\prime}}} \quad v_{z^{\prime}}=-\frac{\hat{C}_{\mathrm{x}^{\prime} x^{\prime} z^{\prime} z^{\prime}}}{\hat{C}_{z^{\prime} y^{\prime} z^{\prime} y^{\prime}}}, \quad G_{z^{\prime}}=\frac{1}{\hat{C}_{z^{\prime} y^{\prime} z^{\prime} y^{\prime}}}, \\
E_{x^{\prime}}=\frac{1}{\hat{C}_{\mathrm{x}^{\prime} x^{\prime} x^{\prime} x^{\prime}}}, \quad v_{\mathrm{x}^{\prime}}=-\frac{\hat{C}_{\mathrm{x}^{\prime} x^{\prime} y^{\prime} y^{\prime}}}{\hat{C}_{\mathrm{x}^{\prime} x^{\prime} x^{\prime} x^{\prime}}}
\end{gathered}
$$

なお，図-11のフローの (f) で， $\xi=0^{\circ}$ と特定されたとき は，式(25)のAの6行1列と2列が無限大になる。この場合 はTalesnick and Ringel ${ }^{21)}$ が提案する方法で弾性パラメータ を特定する。この方法は図-15のように，軸圧縮(a), ね じりせん断(b), 内外圧増分(c)の載荷をそれぞれ行うこ とで, 式(27)から $\xi=0^{\circ}$ 場合の弾性パラメータを求める 手法である。

$$
\begin{aligned}
& \text { (a)より }: E_{\mathrm{z}^{\prime}}=\frac{\Delta \sigma_{\mathrm{a}}}{\Delta \varepsilon_{\mathrm{a}}}, v_{\mathrm{z}^{\prime}}=-\frac{2 \Delta \varepsilon_{\mathrm{X}}}{\Delta \varepsilon_{\mathrm{Z}}} \\
& \text { (b)より }: G_{\mathrm{z}^{\prime}}=\frac{\Delta \sigma_{\mathrm{z} \Theta}}{\Delta \varepsilon_{\mathrm{z} \Theta}} \\
& \text { (c)より }: E_{\mathrm{x}^{\prime}}=\frac{\Delta p}{2 \Delta \varepsilon_{\mathrm{R}}}, v_{\mathrm{x}^{\prime}}=-\frac{\Delta \varepsilon_{\Theta}}{\Delta \varepsilon_{\mathrm{R}}}
\end{aligned}
$$

$\Delta p$ は内外圧で， $\Delta \varepsilon_{\Theta}$ と $\Delta \varepsilon$ は内外圧増分を与えた場合の円 周方向と半径方向のひずみ増分である.なお， $\xi=0^{\circ}$ で軸 対称条件を満たすため, 中空円筒試験体は(a), (b), (c)の載

荷モードで要素の挙動をする. $\Delta \varepsilon_{\Theta}$ と $\Delta \&$ は, この載荷モ 一ドで得た $(X, Y, Z)$ 座標のひずみを式(11)と同様に（R, $\Theta, Z)$ 座標系に変換して得られる.

以上より，原位置岩盤ねじりせん断試験において，等 方圧密とねじりせん断を行えば，計測する応力や変形を 用いて異方性の方向と弾性パラメータが特定できること がわかった．著者らが提案した三軸試験での異方性の特

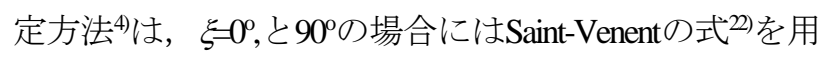
いて経験的にG，を求めていたが，本論文で提案した手 法によれば, 同ケースにおいても全ての弾性パラメータ を正確に求められる.

\section{4. 原位置岩盤ねじりせん断試験による異方性の特 定に測定誤差が及ぼす影響の分析}

3章では原位置岩盤ねじりせん断試験により, 計測值 から異方性の卓越方向と面内等方弾性体の弾性パラメー タを逆算できることを示した。しかし，実際の試験では， ひずみゲージの計測には許容誤差や設置方向の僅かなず れ，電気信号のノイズ等に起因する測定誤差が生じる. また，計測する応力分布は分割ロードセルの個数に依存 してフィッティング誤差が生じる可能性もある. ここで

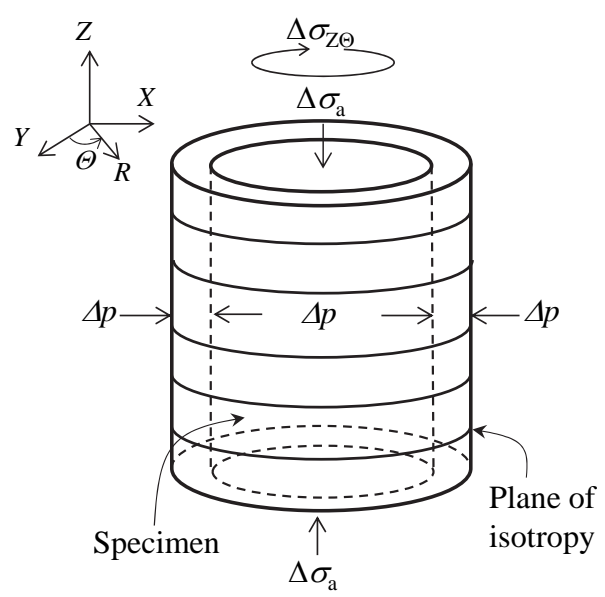

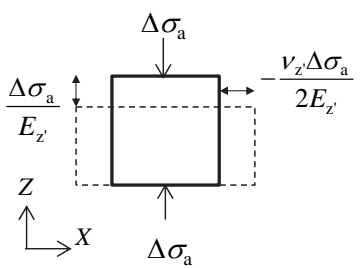

(a) 軸圧縮

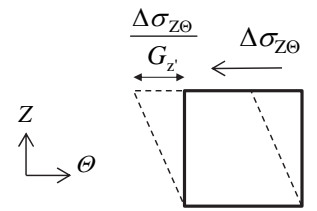

(b) ねじりせん断

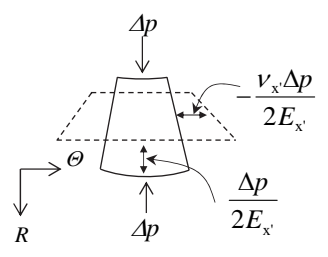

(c) 内外圧増分を載荷

図-15 $\xi=0^{\circ}$ 場合の弾性パラメータの取得方法 ${ }^{21)}$ (左 : 試験体, 右 : 各載荷時の単位要素の変形) 




(a) $r_{\mathrm{ij}}$ の頻度

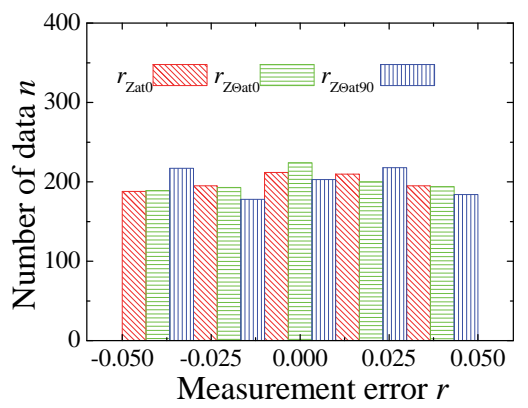

(b) $\left(r_{\mathrm{Za} 0}, r_{\mathrm{Za} \Theta 0}, r_{\mathrm{Z} \odot \mathrm{a} 90)}\right)$ 頻度

図-16＼cjkstart誤差の設計（ $\alpha=0.7$ のケース）

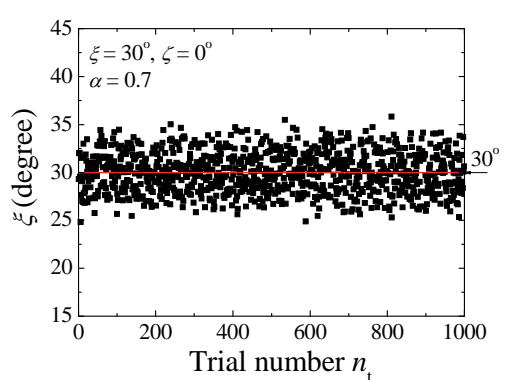

(a) $n_{\mathrm{t}}$ と の関係



(b) $n_{\mathrm{t}}$ と $E_{\mathrm{z}}$ の関係

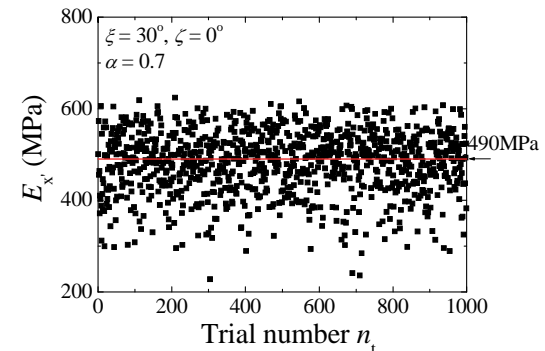

(c) $n_{\mathrm{t}}$ と $E_{\mathrm{X}}$ の関係

図-17 $n_{\mathrm{t}}$ と構成パラメータの関係

は，このような誤差が，計算される構成パラメータに及 ぼす影響を把握するため，意困的に誤差を与えたひずみ と応力を計測值と仮定して構成パラメータを算出し，真 值と比較することで測定誤差に対する提案手法の感度や 適用性を検討する。 この感度分析では，Graham \& Houlsby ${ }^{23)}$ と同様の異方性パラメータ $\alpha$ を式(28)のように導入す る.

$$
\alpha=\sqrt{\frac{E_{\mathrm{x}^{\prime}}}{E_{\mathrm{z}^{\prime}}}}=\frac{G_{\mathrm{x}^{\prime}}}{G_{\mathrm{z}^{\prime}}}=\frac{v_{\mathrm{x}^{\prime}}}{v_{\mathrm{z}^{\prime}}}
$$

$z$ 方向と $x^{\prime} y^{\prime}$ 面のヤング率の比の平方根が，ポアソン比と せん断岡性率の比に等しいと仮定することで，5つの弾 性パラメータを（ $\left.E_{\mathbb{z}}, v, \alpha\right)$ の3つに減らすことができ, パラメトリックな分析が容易になる. この異方性パラメ 一タ $\alpha$ は，各弾性パラメータの比に対する式(23)の拘束 条件の下で異方性の程度を表し， $\alpha=1.0$ の場合は等方弾

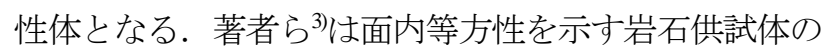
室内試験の結果から式(27)の妥当性や $\alpha$ の取り得る範囲 を検討しており，この分析でも $\alpha=0.7 \sim 1.2 の$ 範囲で感度 分析を行った. なお, 異方性の卓越方向は $(\zeta, \xi)=\left(0^{\circ}\right.$, 30) で一定とした.

感度分析の入力值に用いたのは，等方圧密時の $(X$, $\left.Y^{\prime}, Z\right)$ 座標系のひずみテンソル $\boldsymbol{E}_{\mathrm{ij}}$ ，等方圧密応力 $\sigma$ とね じりせん断時のせん断ひずみ増分 $\Delta \varepsilon Z$ と $\Theta=0^{\circ}, 90^{\circ}$ 応力

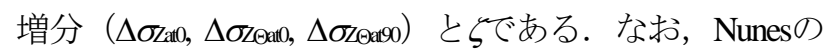
分析 ${ }^{13)}$ に倣い，ロードセルや水圧計で計測する等方圧密


真值と仮定する.

本検討では， 新 ${ }^{14)} と$ 同様に真值から士 $10 \%$ の範囲でラ ンダムにひずみの測定誤差を，またロードセルのフィッ ティング誤差を $\pm 5 \%$ の範囲で与えた，従って，ここで

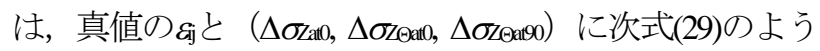
にひずみの測定誤差 $r_{\mathrm{ij}}$ およ゙フィッティング誤差（rzato,





$$
\begin{aligned}
& \varepsilon_{\mathrm{ij}}=\varepsilon_{\mathrm{ij}}+r_{\mathrm{ij}} \\
& \Delta \bar{\sigma}_{\mathrm{Zat} 0}=\Delta \sigma_{\mathrm{Zat} 0}+r_{\mathrm{Zat} 0}
\end{aligned}
$$

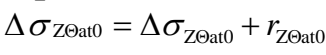

$$
\begin{aligned}
& \Delta \sigma_{\mathrm{Z} \Theta \mathrm{a}+90}=\Delta \sigma_{\mathrm{Z \Theta at} 90}+r_{\mathrm{Z \Theta at} 90}
\end{aligned}
$$

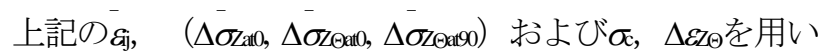
て，図-11に示した提案手法のフローに従って構成パラ メータを求め, 真值と比較分析する. 図-16の頻度分布 に試行回数 $n_{\mathrm{i}}=1000$ 回について実際に与えた誤差 $r_{\mathrm{ij}}$ と（ $r_{\mathrm{Za} a}$, rZGat0，rZOa190）が一様に分布することを示す。なお， $n_{\mathrm{l}}=10000$ 回での解析との比較から， $n_{\mathrm{l}}=1000$ で十分な試行 回数であることを確認している.

検討した中で最も異方性が強い $\alpha=0.7$ ケケース $\left(E_{z^{\prime}}=\right.$ 1000MPa, $\left.v^{\prime}=0.3, G_{\mathrm{z}^{\prime}}=289 \mathrm{MPa}, E_{\mathrm{x}^{\prime}}=490 \mathrm{MPa}, w^{\prime}=0.21\right)$ で $n_{\mathrm{t}}$ と構成パラメータの関係の一例を図-17に示す。同困は $n_{\mathrm{t}}$ と $\xi E_{\mathrm{z}}$ および $E_{\mathrm{x}}$ の関係を示し，1000回の試行で得られた 

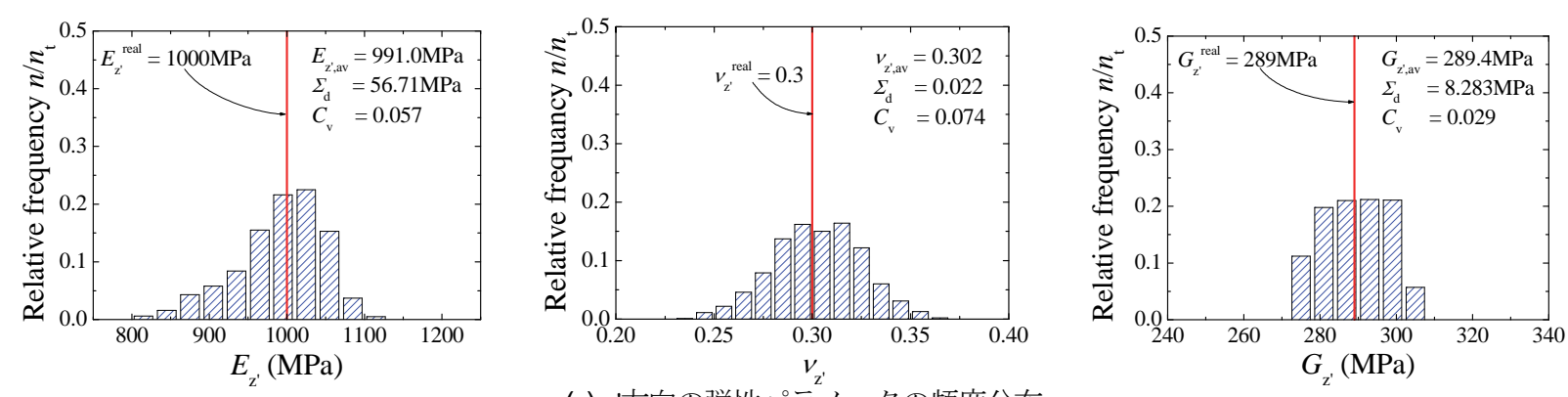

(a) $z^{\prime}$ 方向の弾性パラ゙メータの頻度分布
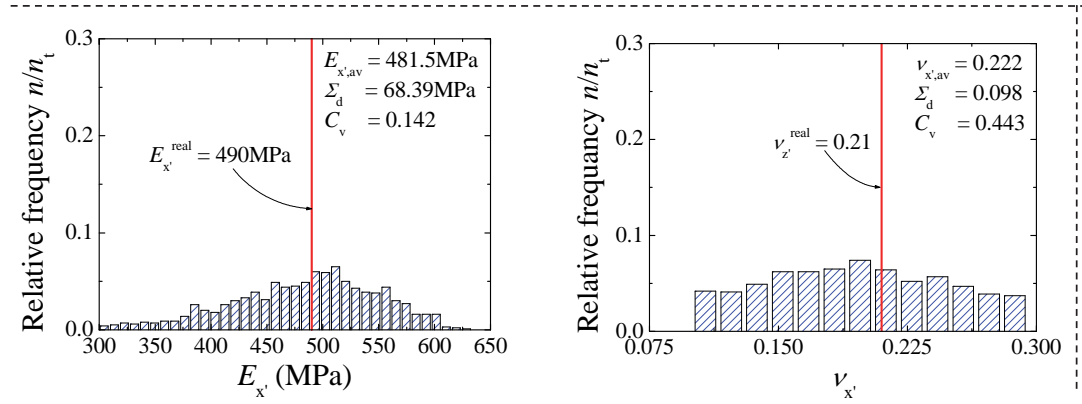

(b) $x^{\prime}, y^{\prime}$ 方向の弾性パラメータの頻度分布

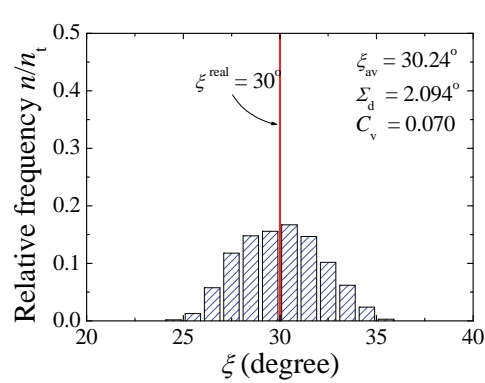

(c) 弜頻度分布

図-18乡おおび弾性パラメータの頻度分布（ $\left.\alpha=0.7, n_{\mathrm{l}}=1000\right)$
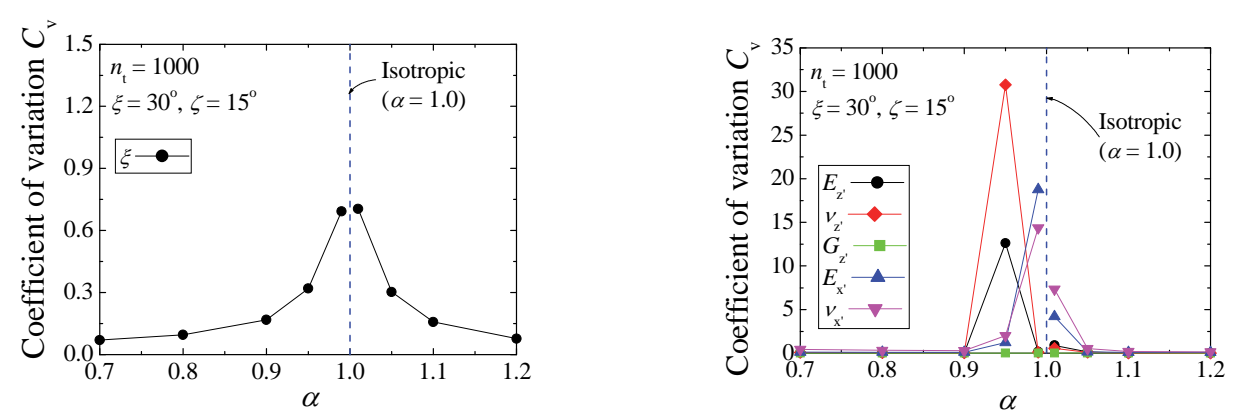

図-19 $\alpha$ と構成パラメータの関係 (左 : $\xi$, 右 : 弾性パラメータ)

構成パラメータを表す，このケースでは，いずれの構成 パラメータでも，真值の近傍にデータが一様に集中して いることがわかる．図-18には図-17と同様のケースで計 算したデータの頻度分布を示寸. 図-18(a)(b)が弾性パラ メータ，図-18(c)がほの頻度分布を表しており，縦軸は各 構成パラメータの頻度 $n$ を試行回数 $n_{\mathrm{t}}$ で正規化し，相対 頻度 $n / n_{\mathrm{t}}$ とした．同図には，構成パラメータ毎の平均值 と標準偏差と変動係数も示し, それぞれ添え字 $\mathrm{av}$ と記号 $\Sigma$ ¿ $C_{\mathrm{v}}$ で表す，全ての構成パラメータの頻度分布で，真 值をピークとした正規分布に近い結果となる．いずれの パラメータでも変動係数 $C_{v}$ は小さく, $C_{\mathrm{V}}$ の最大值は $w$ の 変動係数 $C_{\mathrm{V}}=0.44$ で, 最小值は $G_{L}$ の変動係数 $C_{\mathrm{V}}=0.03$ であ る. このように，異方性が強い場合（ $\alpha=0.7 ）$ にはひず みの誤差を $\pm 10 \%$ ， ロードセルのフィッティング誤差を 土5\%と大きい誤差を想定しても安定して構成パラメー 夕を取得できることがわかった，それに対し，異方性が 弱い場合 $(\alpha=1.0)$ には, 変形特性が等方に近く, 得ら
れる構成パラメータが安定に求められない可能性がある. 各構成パラメータに関するC 2 との関係を図-19に示す. 求める $\xi$ 弾性パラメータは $0.90<\alpha<1.10$ になるとばら つきが増大寸る傾向にあり, 弾性パラメータの中では, $G_{z}$ 以外が特に大きくばらつく．このような岩盤が等方 的な岡性になるに従って起こる異方性解析法の不安定性 は，提案手法に限らず他の方法例え゙13や14)でも同様に起こ りうる. 最後に, 表-1に本検討と Nunes ${ }^{13}$ によって行われ た同様の分析結果と比較する. Nunesの検討では，表-2 のようにらの設定や $G_{z}$ を求める手法22が異なるものの, 本研究と同様にヤング率の比が2倍程度の異方性を想定 している. 本研究ではロードセルの誤差も考慮している が，提案手法で得られた構成パラメータのばらつきがほ ぼ同程度あるいはそれ以下であり，提案手法の方が高い 精度で異方性を評価できると言える。

以上より， $\alpha<0.9 ，$ また $\alpha>1.1$ (ヤング率の差が1割 以上の強い異方性を有する場合）の範囲では，提案手法 


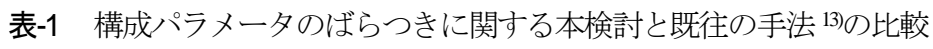

\begin{tabular}{|c|c|c|c|c|c|c|c|c|}
\hline \multirow{2}{*}{ 手法 } & \multicolumn{7}{|c|}{ 変動係数 $C_{\mathrm{v}}$} & \multirow{2}{*}{ 備考 } \\
\hline & $\zeta$ & $\xi$ & $E_{z^{\prime}}$ & $v_{\mathrm{Z}^{\prime}}$ & $G_{Z^{\prime}}$ & $E_{\mathrm{x}^{\prime}}$ & $v_{\mathrm{x}^{\prime}}$ & \\
\hline $\begin{array}{l}\text { This study } \\
(\alpha=0.7)\end{array}$ & - & 0.070 & 0.057 & 0.074 & 0.029 & 0.142 & 0.443 & $\begin{array}{c}r_{\mathrm{ij}}= \pm 10 \% \\
r= \pm 5 \% \text { (for load cells) }\end{array}$ \\
\hline Nunes(2002) ${ }^{13)}$ & 0.117 & 0.248 & 0.060 & 0.120 & - & 0.100 & 0.470 & $\begin{array}{c}r_{\mathrm{ij}}= \pm 10 \% \\
r= \pm 0 \% \text { (for load cells) }\end{array}$ \\
\hline
\end{tabular}

表-2Ｎunesの手法 13)で用いられた構成パラメータ

\begin{tabular}{c|c|c|c|c|c|c|c|c}
\hline 手法 & $\zeta$ & $\xi$ & $E_{z^{\prime}}$ & $v_{z^{\prime}}$ & $G_{z^{\prime}}$ & $E_{\mathrm{x}^{\prime}}$ & $v_{\mathrm{X}^{\prime}}$ & 備考 \\
\hline Nunes(2002) & $30^{\circ}$ & $60^{\circ}$ & $30 \mathrm{GPa}$ & 0.25 & - & $60 \mathrm{GPa}$ & 0.15 & $\begin{array}{c}G_{\mathrm{z}^{\prime}} \text { はSaint-Venant } \\
\text { 手法で求める }\end{array}$ \\
\hline
\end{tabular}

によって安定して構成パラメータを特定できることがわ かった. また， $0.9<\alpha<1.1$ 範囲の等方性に近いケース

（ヤング率の差が1割以下の弱い異方性を有する場合） では，測定誤差の影響を受ける可能性があり注意が必要 である.

\section{5. まとめ}

従来，岩盤の力学特性の異方性を調査する際には，方 向を変えた複数のサンプリングコアの試験を行う必要が あり，試験時間やコスト面で効率的でない上に異方性の 方向を必ずしも特定できなかった，そのため，著者らは， 少ない試験回数で異方性を調査できる原位置岩盤ねじり せん断試験を開発した，本論文では，堆積岩などのモデ ル化に用いられる面内等方弾性体を対象とし，原位置岩 盤ねじりせん断試験の計測項目を用いて，1回の試験に より弾性パラメータおよび異方性の卓越方向を特定でき ることを示した．提案手法では，任意の方向性を持つ異 方性岩盤に対し, 著者らが提案した三軸試験4で異方性 を特定するよりも異方性の方向に依らずに正確な弾性パ ラメータが得られることを示すと伴に，提案手法に及ぼ 寸測定誤差の影響や提案手法の適用性を検討寸るために 測定誤差に関する感度分析も行った．弾性パラメータの 異方性の程度を変化させて検討した結果, 異方性が小さ い場合（ヤング率の差が1割以下の場合）を除き，安定 して構成パラメータを取得できることがわかった。

\section{参考文献}

1) 赤井浩一, 山本和夫, 有岡正樹 : 結晶片岩の構造異 方性に関する実験的研究，土質工学会論文報告集， 第 170 号, pp. 23-36, 1969.

2) Oka, F., Kimoto, S., Kobayashi, H. and Adachi, T.: Anisotropic behavior of soft sedimentary rock, Soils and Foundations, Vol. 42, No. 5, pp. 59-70, 2002.

3）富樫陽太，菊本統，谷和夫：面内等方弾性を仮定し
た岩盤が三軸応力下で示す非三軸性，地盤工学ジャ ーナル, Vol.9, No. 4, pp. 479-493, 2014.

4）富樫陽太，菊本統，谷和夫：三軸試験による岩盤の 変形異方性の特定方法, 地盤工学ジャーナル, Vol. 10, No. 2, pp. 201-211, 2015.

5) Togashi, Y., Tani, K. and Kikumoto, M.: Proposal of the new in-situ torsional testing method and analysis of test results for anisotropic rock masses, Adv. Soil Mech. and Geotech. Eng. (Proc. 5th iYGEC.), Vol. 2, pp. 387-390, 2013.

6) 岡田哲実, 野崎隆司, 池見元宣, 谷和夫 : 電中研式 原位置岩盤力学試験法の開発, 電力中央研究所報告, U02023, pp. 10-11, 2003.

7) 山口柏樹 : 弾 - 塑性力学, pp. 45-47, 森北出版, 1975.

8) Goodman, R. E.: Introduction to Rock Mechanics, Second Edition, John Wiley and Sons, pp. 196-197, 1989.

9) Amadei, B.: Importance of anisotropy when estimating and measuring in situ stresses in rock, Int. J. Rock Mech. and Min. Sci., Vol. 33, No. 3, pp. 293-325, 1996.

10) 冨田佳宏: 弾塑性力学の基礎と応用, pp. 25-26, 森 北出版， 1995.

11) 西澤修: 岩石の地震波速度とその異方性 : エネルギ 一論からのアプローチ, 物理探査, 第 62 巻, 第 4 号, pp. 397-419, 2009.

12) 菊本統, 谷和夫, 岡田哲実, 高倉望, 荻原啓太 : ひ ずみテンソル算出システム・ひずみ計貼付方向決定 方法・ひずみテンソル算出方法及びひずみテンソル 算出プログラム，特願 2013-251347， 2013.

13) Nunes, A. L. L. S.: A new method for determination of transverse isotropic orientation and the associated elastic parameters for intact rock, Int. J. of Rock Mech. and Min. Sci., Vol. 39, No. 2, pp. 257-273, 2002.

14）新孝一：地盤の異方弾性係数の実用的な測定解析法, 土木学会論文集, No. 722/III-61, pp. 231-243， 2002.

15) Gasparre, A., Nishimura, S., Minh, N. A., Coop, M. R. and Jardine, R. J.: The stiffness of natural London clay, Geotechnique, Vol. 57, No. 1, pp. 33-47, 2007.

16) Nishimura, S.: Assessment of anisotropic elastic parameters of saturated clay measured in triaxial apparatus: Appraisal of techniques and derivation procedures, Soils and Foundations, Vol. 54, No. 3, pp. 364-376, 2014.

17) 菊本統, 谷和夫, 富樫陽太 : 原位置岩盤試験方法お よび装置，特願 2013-148114 号，特開 2015-021767 号， 2013. 
18) 石原研而：土質動力学の基礎, pp. 136-137, 鹿島出 版会, 1976.

19) Kohata, Y., Tatsuoka, F., Wang, L., Jiang, G. L., Hoque, E. and Kodaka, T.: Modeling the non-linear deformation properties of stiff geomaterials, Geotechnique, Vol. 47, No. 3, pp. 563-580, 1997.

20) Lekhnitskii, S. G., Tsai, S. W. and Cheron, T.: Anisotropic plates, Gordon and Breach Sci., pp. 157-212, 1968.

21) Talesnick, M. L. and Ringel, M.: Completing the hollow cylinder methodology for testing of transversely isotropic rocks: torsion testing, Int. J. Rock Mech. and Min. Sci., Vol.
36, No. 5, pp. 627-639, 1999.

22) Saint Venant, B.: Sur la distribution des élasticités autour de chaque point d'un solide ou d'un milieu de contexture quelconque, particulièrement lorsqu'il est amorphe sans être isotrope, Journal de Math. Pures et Appliquées, Tome VIII (2ème série), pp. 257-293, 1863.

23) Graham, J. and Houlsby, G. T.: Anisotropic elasticity of a natural clay, Geotechnique, Vol. 33, No. 2, pp. 165-180, 1983.

(2015. 3.24 受付)

\section{DETERMINATION OF DEFORMATION PROPERTIES FOR ANISOTROPIC ROCK MASSES BY IN-SITU TORSIONAL SHEAR TESTING}

\section{Yota TOGASHI, Kazuo TANI and Mamoru KIKUMOTO}

Deformation characteristics of rock masses are often significantly anisotropic due to discontinuities e.g. sedimentary planes and joints. Anisotropic properties of rock masses are commonly obtained by several triaxial tests using rock cores sampled to different orientations, but which is costly and time consuming. In this study in-situ torsional shear test for rock masses is proposed by the authors. Anisotropic deformation properties can be obtained by fewer tests than the conventional testing method. In this paper, for developing testing methods, a method of determining constitutive parameters for transversely isotropic rock masses is proposed. In this proposed method, the directions of anisotropy are determined by the strain responses under isotropic consolidation and 5 elastic parameters of transversely isotropic rocks are determined by both strain responses during isotropic consolidation and the distributed stress responses during torsional shearing. 